\title{
Oiva Ketonen
}

\section{Ihmisen olemisesta ${ }^{1)}$}

\begin{abstract}
Ketonen, Oiva. 1983. Ihmisen olemisesta. Aikuiskasvatus 3, 2, 45-51. - Artikkelissa tarkastellaan ihmisen olemusta kasvatustoiminnan lähtökohtana. Huomiota kiinnitetään luovuuteen, omakohtaisen maailmankatsomuksen muodostamisen tärkeyteen sekä tarkastellaan eskapismin eri muotoja. Artikkelissa arvioidaan myös kasvatustieteen tehtäviä ja aikuiskasvatuksen tavoitteita.
\end{abstract}

Näyttää siltä, että ihmisen tietoisuus on aina, ja sen täytyy aina olla, jollakin erityiseliä tavalla järjestynyt, jotta hän voisi elää ja olla olemassa järjellisenä, yhteisöllisenä olentona. Ihmisellä täytyy olla jokin henkinen keskus, elämän idea tai tarkoitus, jonka ympärille ajatukset ja toimet voivat keskittyä suhteellisen yhtenäiseksi kokonaisuudeksi. Se on perusta yksilön minuuden ja hänen identiteettinsä määrittelylle. Uskonto, ideologia, elämän muoto ja tieteellisen asennoitumisen tapa tai muu keskeinen perinne ovat sellaisia yksilön, yhteisön ja kulttuurin jäsentymisen peruskuvioita. Löytäessään sellaisen peruskatsomuksen tai herätessään siihen ihminen tuntee löytävänsä lopullisen totuuden.

Tutkijan laatima tai omaksuma yleinen teoria on hänelle yleensä paljon enemmän kuin vain käsitys asiain laadusta ja järjestyksestä. Se on hänen elämänuskonsa, se pyramidi, jonka hän rakentaa ja jonka ympärille hän kokoaa tietoisuutensa. "Kukin meistä mittansa mukaan pyramideja pystyttää’'. Uuno Kailas sanoi tällä runokuvalla periaatteessa saman, mitä Thomas Kuhn on myöhemmin sanonut puhuessaan tieteen paradigmoista, tutkimukselle suuntaa antavista yleisistä hypoteeseista.

Tietoisuuden jäsentyminen merkitsee toisaalta, että ihminen on persoonallisuudessaan vastaavasti urautunut. Urautumista halveksitaan, mutta halveksija on itse myös urautunut. Urautuminen ei ole erehdys eikä onnettomuus, se tulee ihmisen olemisen perusteista ja kuuluu hänen normaaliin luontoonsa. Se antaa hänelle turvaa. Urautumisen voi nopeasti huomata arkielämän tilanteissakin tai lehtiä lukiessaan ja esitelmiä kuunnellessaan. Kukin ihminen esit-

1) Tämä artikkeli on lyhennelmä Kansalais- ja työväenopistojen liiton seminaarissa 4.1.1983 Aulangolla pidetystä alustuksesta. tää toistuvasti, vain vähäisin muunnelmin aina samoja omia uskojaan ja peruskatsomuksiaan, joita mitkään vastahuomautukset eivät yleensä muuta miksikään. Esitelmöitsijäkin pitää periaatteessa aina saman esitelmän, vaikka eri sanoin. Ehkä se on syy, että niiden pitäminen alkaa vähitellen kyllästyttää esitelmöitsijää itseäänkin. Jos esitelmiä pitää toistuvasti samoissa maisemissa, niin lopulta, kuten eräs tuttavani totesi, voi etukäteen tietää keskusteluttakin, ketkä käyttävät puheenvuoroja ja mitä he sanovat. Kaikkein tärkein esimerkki urautumisesta on itse establisment, oikeaksi katsotut yleiset käsitykset.

Ihminen ei juuri ymmärrä, arvosta eikä näekään muuta kuin mikä sopii hänen minuutensa peruskuvioihin, muu ei ole hänelle täysin todellista. Filosofilla on omat taustakuvionsa, jotka eivät ehkä aina tule elämän arkisissa, mutta tulevat kyllä toisenlaisissa tilanteissa toistuvasti näkyviin. Ihminen muuttuu näissä suhteissa yleensä vain, kun hän joutuu käymään läpi vaikean kriisin, oli se sitten tieteellinen tai muunlainen elämän murros.

Ihminen ei yleensä halua nähdä taikka myöntää asioita, jotka asettaisivat hänen monien vuosien kuluessa vaivoin rakentamansa todellisuuden kuvan kyseenalaiseksi. Usein hänellä ei ole siihen varaakaan. Jos hänen käsityksensä todellisuudesta, sen mukaiset menetelmät ja muu mitä siihen kuuluu, on häntä hyvin palvellut, niin se pyramidi, jonka hän käsityksensä ympärille on rakentanut, sitoo ja velvoittaa häntä. Luopuminen todellisuuden käsityksestä merkitsee samaa kuin myöntää, että työ, jota hän on pitkään tehnyt, on vailla sitä perimmäistä arvoa, jonka hän työlleen antoi. Vain hyvin vahva tai erikoinen ihminen voi olla valmis sellaiseen.

Todella uusia asioita luomaan pystyvä yksilö näyttää olevan ihmisten joukossa poikkeus. 
Luovuus, josta varsinkin liike-elämässä paljon puhutaan, ei sanan vaativassa mielessä liene ihmisen lajityypillinen ominaisuus. Ihmiselle lajina näyttää pikemmin kuuluvan vain kyky omaksua ja olla omaksumalleen uskollinen.

Luovuus ei ensi sijassa ole älyllistä keksimisen kykyä, vaan moraalinen ominaisuus. En kuitenkaan tarkoita, että rikos olisi luova teko, vaikka historian kuluessa luovuutta on usein pidetty rikollisuuden luontoisena. Peruskeksinnöt ovat usein yksinkertaisia. Suomalaisen kuuluisan arkkitehdin eräs nerokkaaksi sanottu luomus oli siinä, että hän muutti viivan, joka aina oli ollut suora, loivasti kaarevaksi. Se ei ollut vaikea älyllinen keksintö. Se ei vaatinut suurta mielikuvitusta, mutta se muutti kokonaisuutta. Vaati rohkeutta käydä tuntemattomaan ja rakentaa uusista aineksista kokonaisuus, jonka laatua ei etukäteen tuntenut. Toinen asia on, onko luovuus aina edes hyväksi? Pitääkö aina yrittää muuttua, irtautua menneisyydestä? En varauksitta usko siihen. Luovuus palvelee ihmistä vain, jos siitä uudesta, mitä on saatu aikaan, kyetään rakentamaan ihmistä palveleva kokonaisuus. Mutta niin ei yleensä käy. Useimmat ihmiset jäävät tuuliajolle.

Ihmisellä on viettymys esikuvien seuraamiseen ja sen mukainen valmius luovuttaa vastuu johtajayksilölle tai ryhmälle. Vastaavasti johtajayksilöllä tai ryhmällä on viettymys valtaan, joka ilmenee pyrkimyksenä ulottaa oma laatu, so. omat arvot, totuudet, menetelmät ja tavat muita koskeviksi ja pitää huolta oman laadun jatkuvuudesta.

Ihmisen minuudessa on jotain ehdotonta, ikään kuin ylhäältä käsin annettua. Siitäkin, mitä ihminen myöhemmälläkin iällä itse elämän paineiden alaisena päättää, jos se muovaa hänen persoonallisuuttaan, tulee velvoitus, joka tuntuu olevan hänen itsensä yläpuolella. Hänen omat ratkaisunsa tulevat hänelle jumaliksi, jotka sitovat ja velvoittavat häntä ja joiden edessä hän ei enää ole vapaa. Hänellä on sisäinen vapauderı kokemuksensa. Se ilmentää samalla sekä hänen sidonnaisuuttaan että hänen olemistansa sopusoinnussa oman itsensä kanssa.

Eräs esimerkki: Psykoanalyyttisessä konferenssissa Haikossa kesällä 1980 mainittiin Freudin kuuluisaksi tullut erehdys. Freud oli uransa alkuvaiheissa uskonut tosiksi monien naispotilaittensa väitteet siitä, että he olisivat nuorena joutuneet isänsä viettelemiksi. Ennen pitkää kävi ilmi, että nämä kertomukset eivät olleet tosia vaan olivat mielikuvituksen tuotetta. Erehdyksen paljastuminen sai Freudin kääntämään psykoanalyysin kehittämisessä huomionsa kokonaan yksilöterapiaan. Eräs aktiivinen konferenssin osanottaja sanoi puheenvuorossaan, että Freud tämän virheellisen johtopäätöksensä kautta oli viivyttänyt 50 vuodella perheterapian syntymistä ja väite olikin oikea. Jos Freud olisi kiinnittänyt huomionsa siihen, millä tavoin isä - ja ympäristö yleensä käytöksellään oli saattanut vaikuttaa tyttäreensä ja edistää sanotun kaltaisten kuvitelmien syntymistä, perheterapia epäilemättä olisi syntynyt paljon aikaisemmin.

Mutta merkillistä oli, että Freudia syytettiin siitä mitä hänen seuraajansa kahden miespolven aikana laiminlöivät tai jättivät tekemättä. Hehän olisivat voineet tehdä sen! Miksi he eivät tehneet sitä minkä Freud jätti tekemättä? Kai sen vuoksi, että Freudin oppi oli ollut ja on vieläkin niille jotka sen omaksuvat pitkään enemmän kuin tieteellinen teoria tai käsitys asioista. Se oli ja on, niin kuin käänteentekevät teoriat yleensä ovat, tapa hahmottaa ja tulkita todellisuutta, uskonasia joka muovaa ihmistä itseään.

\section{Kasvatustieteen tehtäviä}

Ihminen heijastelee sisäisiä ongelmiaan ja ristiriitojaan suhteissaan toisiin ihmisiin ja yhteisöönsä. Ihmisten sisäistä tasapainoa pitäisi pyrkiä parantamaan, jos ihmisten keskinäistä tasa-arvoa ihmisinä halutaan edistää.

En käy suosittelemaan mitään erityisiä toimenpiteitä. Totean vain, että kasvatustieteellinen tutkimus, valitettavasti, ei meillä ole sanottavasti työskennellyt pohjan löytämiseksi sellaisia toimenpiteitä varten. Syynä on, että tutkimus on suuressa määrin keskittynyt rutiiniin ja ulkokohtaisiin näyttöihin.

Yliopisto-opetus ei kasvatustieteissä myöskään kykene antamaan vaativampaa ja tarpeellista, ihmistä ja hänen kulttuuriaan koskevaa tieteellistä yleissivistystä. Käsitykseni on, että terapeuttinen ajattelu ja tutkimus voisi antaa tärkeitä hypoteeseja, mutta sitä vältetään toisaalta siksi, että se on ulkopuolella nykyharrastuksen ja toisaalta siksi, että luullaan sen koskevan vain sairasta ihmistä, mikä ei ollenkaan pidä paikkaansa.

Tässä kritiikissä en ole yksin. Kansliapäällikkö Jaakko Numminen sanoi Joensuussa 22.10.82 kasvatustieteellisestä tutkimuksesta mm. seuraavaa:

"'Erityisesti minua on askarruttanut viimeksi kuluneina vuosina kasvatustieteellisen tutkimuksen osuus. Kun parina viime vuosikymmenenä on seurannut erityisesti koulutuspolitiikan ja kasvatuksen näkökulmasta tutkimuksen mahdollisuuksia ja antia, on valitettavan usein joutunut pettymään. Tuntuu siltä, että 
kasvatustieteellinen tutkimus ei ole pystynyt tuottamaan kovin paljon tietoa valmistelutyön pohjaksi, eri toimintamallien vertailemiseksi ja ylipäätään laajan koulutuspoliittisen uudistustyömme tueksi. Valitettavasti on tunnustaminen, että monet suuret koulu-uudistuksemme on jouduttu tekemään ikään kuin sormituntumalta, vailla riittävää tieteellistä pohjaa. Viime aikoina on mieleen hiipinyt myös epäilys siitä, että kasvatustieteellinen tutkimuskin on "'laitostunut" rajoittaessaan aivan liiaksi tutkimusalueensa "viralliseen" kasvatusympäristöön, lähinnä kouluun.

Koulutustutkimustamme on kritisoitu - ja tämä kritiikki voidaan ehkä laajentaa koskemaan humanistista ja yhteiskuntatieteellistä tutkimusta yleensä - siitä, että se ei pureudu riittävän ajankohtaisiin, tulevaisuuden kannalta merkittäviin kysymyksiin. On esitetty arvostelua, että tuo tutkimus askartelee liian helposti triviaalien tutkimusongelmien kanssa, hautautuu tutkimusmenetelmälliseen keikarointiin ja ehkä alkaa unohtaa koulumaailman ulkopuolella olevat realiteetit ja yhteiskunnallisen kehityksen vaikutukset.

Kun sanon edellä olevan kasvatustieteellisestä tutkimuksesta, on syytä muistaa, että maamme yliopistojen ja korkeakoulujen kasvatustieteen laitoksissa on yli 70 kasvatustieteen professoria ja apulaisprofessoria, jotka edustavat korkeata metodista koulutusta. Olisi mitä toivottavinta, että he tulisivat yliopistollisista laitoksista ulos yhteiskuntaan, sen polttavien ongelmien keskelle, eivätkä pysähtyisi vaarattomiin akateemisiin kysymyksiin, joiden tutkiminen on sinänsä arvokasta, mutta jotka eivät useinkaan liity koulutuspolitiikan kokonaisuuteen."

Tavaton asia sinänsä, että kokonainen tieteenhaara saa valtiovallan edustajan taholta tällaisen puolivirallisen tuomion.

Ei mitään vastinetta alan edustajien taholta: Tämä hiljaisuus antaa aiheen otaksua, että tilanne kenties on vielä oletettua huonompi.

\section{Aikuiskasvatuksen tavoitteet}

Mitä alussa sanoin ihmisestä yleensä tarkoittaa toisin sanoen myös sitä, että se, mitä me katsomme tosiasioiksi tällä hetkellä ja tärkeäksi tulevaisuudessa, ei koskaan ole puhtaita yksinkertaisia tosiasioita, vaan mieltymystemme ja toiveittemme enemmän tai vähemmän ilmeisellä tavalla korostamia tai värittämiä käsityksiä. Nämä käsitykset voivat olla tosia tietyin edellytyksin, mutta juuri näitä edellytyksiä me emme halua yleensä eritellä taikka lausua julki. Tavallisesti ne pystyy hyvin näkemään vain se, joka on kysymyksessä olevan järjestelmän ulkopuolella.

Toiveittemme ja perusnäkemystemme vaikutus on vieläkin ilmeisempi, jos ajattelemme niitä päämääriä, joita tavoittamaan aikuiset on mielestämme yhteisössä koulutettava. Nämä tavoitteet ovat tietysti niitä, jotka ovat meille urautumisemme vuoksi joko ideologisista tai persoonallisista syistä rakkaita ja joiden toteuttamista kunnoittamamme auktoriteetit meiltä odottavat. Koska ne ovat uskonasioitamme, me usein olemme huonosti tietoisia siitä, kuinka paljon ne vaikuttavat toimintaamme ja kuinka radikaalisti me, niiden mukaan toimiessamme, torjumme toisia, ehkä parempiakin vaihtoehtoja.

Meidän pitäisi suunnitelmia tehdessämme eritellä ja ilmaista selvästi niin pitkälle kuin se on inhimillisesti mahdollista ne sekä persoonalliset että yhteisölliset arvot ja tavoitteet, jotka ovat suunnittelun taustalla. Ihmisenä olemisen tärkeimpiä, ehkä kaikkein tärkein tunnusmerkki on tietoisena oleminen, tietoisuus siitä, mitä omat teot ja ratkaisut merkitsevät.

Tämä älköön antako lukijoille käsitystä, että olisin nyt siis valmistautunut esittämään lopullisen totuuden aikuiskasvatuksen päämääristä. Filosofina olen oppinut, että lopullista totuutta ei ole, ja jos olisikin, niin elämää ei kannattaisi yrittää rakentaa sen varaan, sillä se eliitti, joka voisi sen täysin omaksua, olisi joka tapauksessa vähäinen. Muille sellainen totuus olisi saneltava ja pakotettava ja jo tämä soveltamisen tapa osoittaisi nopeasti että se ei ollut sellainen totuus kuin oli otaksuttu. Otaksutut lopulliset totuudet ovat historiallisesti olleet poikkeuksetta välineitä, joiden avulla kulloinenkin hallitseva luokka on toteuttanut valtapoliittisia tarkoituksiaan.

Totuudet ovat paikkansa pitäviä aina ainoastaan tietyin edellytyksin. Mikään ei voi estää sitä, että totuuksiemme edellytykset aikojen muuttuessa muuttuvat, vanhat totuudet murenevat ja katoavat ja uudet tulevat niiden tilalle. Aatteet, niin tärkeitä kuin ne aikanaan ovatkin, ovat vain eräänlaista kertakäyttötavaraa. Ne ovat päteviä vain joillekin ja jotkut vain muutaman vuoden, jotkut vuosikymmeniä ja jotkut kuten suuret uskonnot vuosisatoja. Pysyvältä näyttää vain se, mikä on vaikeinta, mikä koskee ihmisten välisiä suhteita ja näiden suhteiden merkitystä.

Koulutuksen tavoitteiden ja päämäärien asettaminen on menneinä vuosisatoina yleensä 
ollut yksinkertainen tehtävä. Todellisuutta hahmottavana ideologiana kristinusko on ollut länsimaissa keskeinen, ja suhteellisen vahva valtiovalta on antanut sille tukensa. 1800-luvun puolivälissä Nikolai I asetti kansanvalistuksen päämääräksi entistä paremman yhteisymmärryksen saavuttamisen "kristillisen mielen, valistuksen ja voimassaolevan valtiojärjestyksen välillä"’. Tästä on vielä paljon jäljellä, mutta emme enää ilmaise koulutuksen tavoitteita tällä tavoin. Tieteellinen tutkimus on murentanut pohjaa uskontojen alta, mutta onnistunut siinä vain osittain. Maailmassa on edelleen mahtavia valtakuntia, joiden olemassaolon perustana ovat uskonnolliset tai niihin verrattavat ideologiset dogmit. Dogmien asema on niin vahva, että vapaa tutkimus, jos sitä onkaan, ei saa tai ei kykene asettamaan niiden pätevyyttä kyseenalaiseksi. Ja viime ajat ovat osoittaneet, että uskonnolliset järjestelmät kykenevät edelleen samaan kiihkoon ja hävitykseen - mistä olemme pyrkineet pääsemään irti - joka oli niille ominainen menneinä vuosisatoina. Ilmeisesti kysymyksessä ovat voimat, jotka täytyy kaikessa koulutuksessa ottaa kielteisinä tai myönteisinä jollain tavoin huomioon.

Meikäläinen koulutus korostaa eri tavoin edelleen valtion ja kansakunnan arvovaltaa ja sen taustalla olevaa ideologiaa. Yleensä tämä korostus on, niinkuin pienelle kansalle sopiikin, ollut maltillista joskin sekä tunteeseen että järkeen vetoavaa. Käsitykseni on, että koulutuksessa on aina oleva jokin sellainen aatteellinen tai vastaava korostus.

On ilmeistä, että jatkuvasti lisääntyvä kansainvälinen kanssakäyminen asettaa koulutukselle uusia haasteita. Toisenlaisten kielten ja kulttuurien ja toisenlaisten elämäntapojen ja olosuhteiden takaa on opittava tuntemaan periaatteessa samanlainen ihminen, joka itsekin olemme ja opittava suhtautumaan häneen sellaisena. Mutta jos kysyttäisiin, onko kasvatus kansainvälisyyteen ja työhön koko ihmiskunnan hyväksi siis katsottava siksi aatteelliseksi haasteeksi, johon tulevaisuudessa on ensisijaisesti vastattava, ja siten asetettava koulutuksen päätavoitteeksi, niin vastaukseni olisi ilman muuta kielteinen. Me tosin uneksimme yleisestä kaikille samasta maailmankulttuurista, joka olisi riippumaton kansallistunteista ja kansallisista erikoispiirteistä. Sellaisella utopialla on aatteena arvonsa, mutta en usko siihen. Elämän mielekkyys riippuu, kuten olemme tutkimuksenkin tasolla oppineet tietämään, ratkaisevasti siitä erityisestä, jota rakastamme, erityisestä ihmisestä, jonka tahdomme elä- mämme seuralaiseksi, perheestä, ystävistä, ryhmäkulttuurista ja kansallisesta omaleimaisuudesta. Ihminen on persoonallinen ihminen ensisijaisesti perheen, ryhmän ja kulttuurin jäsenenä, jossa hän on kasvanut.

Ehkä joskus kaukaisessa tulevaisuudessa ihminen kykenee elämään onnellista elämää maailmassa, joka on kaikkialla samanlainen ja jossa ihmisen lähimmäinen on kuka tahansa ihminen. Mutta siihen kulunee monia tuhansia vuosia ja siihen luultavasti tarvitaan geneettisiä muutoksia ihmisissä. Nyt emme halua sellaista elämää. Me haluamme pitää lähimmäisinämme ne, jotka ovat olleet ja ovat mieltymyksemme mukaan meitä lähinnä ja joihin nähden meillä on erityisiä lain tai tavan mukaisia velvollisuuksia. Tietysti on ihmisiä, jotka tahtovat olla maailmankansalaisia synnyinsijastaan ja kansastaan riippumatta tai ne kieltäen. Sekin on eräs valinta. Mutta se on myös tapa paeta, jos ei jostakin syystä halua olla osana siinä vuorovaikutuksessa, jota elämä on pienempien yhteisöjen tasolla.

Ilman samassa yhteisössä elävien ihmisten läheisyyttä suurin osa nykyihmisistä kokisi elämänsä mielettömäksi ja pirstoutuneeksi. Ihmiset eivät, ilman jonkinlaista henkistä vaurioitumista, kykene, paitsi hyvin hitaasti, luopumaan omasta heimostaan ja kulttuuristaan, eivätkä yleensä myöskään - valitettavasti - kykene sietämään keskuudessaan toisenlaista kulttuuria. Tämä näkyy länsimaissakin, Englannissa, Ruotsissa, Saksassa ja muualla, minne toisen maailmansodan jälkeen on muodostunut merkittäviä uusia vähemmistöjä.

\section{Maailmankatsomuksen muodostuminen}

Mitä tässä olen sanonut perheen, suvun tai kulttuurin merkityksestä jokapäiväisen elämän mielekkyyden perustana, sillä on yleisempi analoginen vastineensa ja ilmenemismuotonsa inhimillisessä kulttuurissa.

Yhtä hyvin kuin lisääntyvä kansainvälinen kanssakäyminen asettaa koulutukselle uusia haasteita, yhtä hyvin ja ehkä enemmänkin on haasteita asettanut ja asettaa elämisen lisääntyvä riippuvuus kaikenlaisesta tekniikasta. Luonnonvarojen väheneminen näyttää vain lisäävän tätä riippuvuutta. Ihminen ei ole halukas palaamaan aikaisempiin vähemmän teknisiin ja vähemmän luontoa kuluttaviin elämisen tapoihin. Lisääntyvä ihmiskunta niiden varassa tuskin edes eläisikään. 
Me voimme kiittää tai moittia tätä elämämme lisääntyvää riippuvuutta tekniikasta. Mutta suhtauduimme siihen miten hyvänsä, on kuitenkin ilmeistä, että se asettaa koulutukselle jatkuvasti uusia vaatimuksia. Ihminen on valmistettava ottamaan paikkansa teknisessä yhteiskunnassa, ja kun hän on aikuinen, hänen mahdollisuuksiaan toimia hänelle kuuluvissa sekä totutuissa että uusissa tehtävissä on jatkuvasti lisättävä. Tietokoneiden ja mikroprosessorien yhteiskunta on toisenlainen kuin nykyinen ja se on hyvin radikaalisti toisenlainen, jos ja kun tämä tekniikka on tullut muidenkin kuin vain nykyisten edistyneiden teollisuusmaiden olennaiseksi osaksi. Sellainen muutos on varmasti edessä, mutta en käy arvaamaan, mitä silloin on koulutukseen sisällytettävä, jotta yhteiskunta toimisi asianmukaisella tavalla.

Koulutus yleensä ottaa huomioon ne käytännön vaatimukset, erityiset tiedot ja taidot, joita yhteiskunnassa tarvitaan. Ne ovat tietysti tärkeitä, mutta en tarkastele niitä sen enempää. Kiinnittäisin huomiota niihin vähemmän näkyviin haasteihin, joihin nykyaikainen koulutus on vastannut yleensä puutteellisesti, ja joiden merkitys tulevaisuudessa käsittääkseni lisääntyy. Tarkoitan alussa viitattuihin liittyviä vaikutuksia, joita elämisellä teknistetyn elämän osana on maailmankatsomuksellisiin asenteisiimme, tai oikeammin sanoen näiden vaikutusten kutakuinkin täydellistä puuttumista, sillä standardisoidut tarpeet tyydyttävällä tekniikalla ei oikeastaan ole mitään katsomuksellista tai elämisen mielekkyyttä luovaa tai korostavaa sisältőä. Näyttää siltä, että tätä tyhjyyttä vieläpä saatetaan pitää teknistyneen elämän hyvänä puolena. Niiden kontaktien yhteydessä, joita minulla on ollut käytännön aikuiskasvatukseen - niitä tosin ei ole ollut paljon - olen aina kuullut valitettavan, että on suhteellisen helppo saada varoja erityisiä taitoja ja tietoja esittelevien kurssien tai luentojen järjestämiseen, mutta vaikeata tai mahdotonta, jos kysymyksessä ovat maailmankatsomukselliset selvittelyt tai maailmankatsomuksen muovaamiseen tähtäävät seminaarit.

Asia on tärkeä koska yksikään ihminen ei elä ilman jonkinlaista maailmankatsomusta tai uskontoa - miten sitä kulloinkin nimitetään - siis jotain persoonallista perusideaa, joka pitää koossa ihmisen minuuden ja määrittelee hänen todellisuutensa. Maailmankatsomus ei ole enempää ylellisyyttä kuin ajanvietettäkään, vaan järjestyneessä yhteisőssä elävän ihmisen olennainen osa. Persoonallista maailmankatsomustakaan ei kulttuuriyhteiskunnassa pidä jättää alkuperäisyyden asteelle eikä ihmistä kohtaamaan sellaisen varassa kaikkia niitä pelkoja ja epävarmuuksia, jotka elämässä ovat tavallisia. Senkin pitää tulla, niinkuin ulkoiset tiedot ja taidot elämän kuluessa tulevat, tietoisen ja tarkoituksellisen muokkauksen kohteeksi. Sen muovaaminen on enemmän kuin tietojen ja taitojen oppimista. Vasta kun eläydymme siihen, mitä opimme, vasta kun se värittää jokapäiväistä persoonallista kokemistamme, se tulee omaa minäämme vahvistavaksi ja selventäväksi katsomulliseksi tekijäksi. Suuret elämän kriisit pakottavat meidät sellaisiin selvennyksiin, mutta katsomuksellista erittelyä pitäisi harrastaa muutoinkin, niin että elämän muutokset eivät olisi liian outoja ja vaikeita ja että sillä tavoin saavutetut olemisen selvennykset eivät jäisi vain niiden etuoikeudeksi, jotka ovat onnistuneet hyvin selviytymään kriiseistään.

Olen tässä käyttänyt sanaa "'maailmankatsomus" hyvin yleisessä merkityksessä. Olen tarkoittanut sillä yleisesti mitä tahansa sellaista katsomusta, käsitysten kokonaisuutta tai omaksuttua perinnettä ja elämän tapaakin, joka tasapainottaa persoonallisuuden, niin että ihminen voi katsomuksensa varassa selviytyä henkisesti vaikeistakin koettelemuksista. Se voi olla filosofinen oppi ihmisen olemuksesta, esim. kokonaiskuva siitä, että ihmisen elämä rajautuu tähän maailmaan tai kaikkine konsekvensseineen kehitelty käsitys siitä, että ihmisellä on aineellisesta olemisesta riippumaton sielu, tai se voi olla muunlainen ateistinen tai uskonnollisten käsitysten muodostama kokonaisuus. Kaikkein useimmin kokoava katsomus luultavasti kuitenkin on ollut suvun ja kansallisen perinteen värittämä elämäntapa ja se tyő, jonka ihminen on tuntenut omakseen ja joka on antanut mielen ja tarkoituksen hänen jokapäiväiselle elämälleen. Vuodenaikojen vaihtelut ja niiden mukana vaihtuva työ ja vastuu siitä saattoi jäsentää maanviljelijän elämän ja antaa tyydytystä, jota koneistettu elämä ei samoissa olosuhteissakaan enää anna. Käsityöläiselle, joka eläytyy työhönsä ja antaa sille arvoa, hänen työnsä on hänen elämänsä. Viulunrakentajalle, joka koputtelee puitaan, eläytyy niiden värähtelyihin ja keittelee lakkojaan, elämä on hänen työnsä ja hänen rakentamiensa viulujen historiaa ja jäsentyy niiden mukaisesti. Filosofiset tai uskonnolliset asiat ovat tietysti jollain tavoin sellaisenkin elämänkuvan taustalla, mutta toissijaisina sunnuntai-asioina, eivät arkipäivän mietteinä.

Teknisessä maailmassa useimmat ihmiset tekevät päivästä toiseen samana toistuvaa yksin- 
kertaista työtä, joka on yleensä vailla yksilöllisen työnteon antamaa kokoavaa katsomuksellista sisältöä. Sellaisen työn tekijä voi järjestää henkisen maailmansa vain muilta oppimisen välityksellä saamansa aineiston, so. perinteen, filosofisten, uskonnollisten tai poliittisten aatteiden varaan.

Eräs maailmankatsomuksen tärkeä ominaisuus on, että sitä ei voida antaa kenellekään valmiina, paitsi ehkä hirveätä aivopesua käyttäen. Etsijälle voidaan antaa vain sen aineksia. Häntä voidaan ohjata tarpeeliiseen erittelyyn ja oikeitten kysymysten asettamiseen, mutta vastaukset hänen on itsensä annettava lähtien omista edellytyksistään. Eikä vastaus ole vastaus, jos toinen sen antaa, oli tämä toinen kuinka etevä auktoriteetti hyvänsä. Vastaus persoonalliseen kysymykseen on vastaus, vain jos asianomainen itse sen löytää omista mietteistään tai toisen sanomasta. Katsomuksen selventäminen on sen vuoksi vaikea ja päättäväisyyttä kysyvä tehtävä. Toiseksi mahdollisuudeksi jää, että henkinen tarve kielletään ja peitetään ajanvietteellä, alkoholilla tai muulla sellaisella.

Niiden ihmisten joukko, joille henkilökohtainen työ antaa tietoisuutta kokoavan, mielekkään elämän sisällön, tulee vastedes olemaan yhä pienempi ja pienempi. Heitä voi teknistyvässă maailmassa pitää etuoikeutettuina. Jos kehitys jatkuu nykyiseen tapaan, niin enin osa tulee olemaan vailla sellaista elämän järjestystä, jonka oma tyő on perinteisesti ihmiselle antanut. Jotain pitäisi tehdä ko. luokkajaon lieventämiseksi. Helsingissä näkee siellä täällä seinään tai plakaattiinkin tekstattuna sanan "työtä". Se on osalta poliittinen iskusana, joka korostaa toimeentulon turvaamista. Mutta sellainen huuto tulee myös paljon syvempää. Se ilmaisee ihmisen tahdon saada elää ihmisen arvoista elämää. Se että se on samailla poliittinen vaatimus, tekee sen myös valtapyrkimysten välikappaleeksi, ja johtaa helposti asian perusinhimillisen merkityksen syrjään asettamiseen.

\section{Todellisuudesta pakeneminen}

Olen koettanut edellä valaista katsomuksellisten näkökohtien huomioonottamisen tarpeellisuutta aikuiskasvatuksessa. Elävässä elämässä niihin liittyvät ongelmat tulevat esiin toisaalta aikuisten ongelmina, toisaalta murrosiän jälkivaiheissa, jolloin ihminen rakentaa aikuisuuttaan. Asia on teknisessäkin yhteis- kunnassa tärkeä siitä syystä, että ihminen ilman sisäisiä ristiriitoja pystyy tehtävissään suorittamaan enemmän kuin se, jota sisäiset ongelmat vaivaavat. Sellainen ihminen on usein myöskin sekä terveempi että raittiimpi ja tarvitsee vähemmän yhteiskunnan palveluksia. Tätä puolta ajatellen on periaatteessa yhdentekevää, millaisesta katsomuksesta on kysymys, so. onko tietoisuutemme järjestäytynyt kokonaisuudeksi filosofisen, uskonnollisen tai humanitaarisen opin, kansallisen ajatuksen tai persoonallisesti onnistuneen elämäntavan tai uran ympärille. Mutta eräs tärkeä ja merkitsevä eroavuus kuitenkin on, se tulee ilmi toisella tavoin, ja siihen tahtoisin lopuksi kiinnittăä huomiota.

Jokainen katsomus - oli se mitä laatua hyvänsä - sisältää tietyn valinnan. Katsomuksen vakiintuessa olemme tehneet valinnan sen välillä, mikä tämän katsomuksen näkökulmasta on tärkeätä, mihin me kiinnitämme huomion ja mitä otamme ympäristöstä vastaan, ja sen välillä, mikä on vähemmän tärkeätä ja minkä torjumme ja jätämme huomiotta. Tällainen valinta kuuluu itse katsomuksen perimmäiseen olemukseen.

Näin siis jokainen katsomus merkitsee samalla myős pakenemista, tiettyä eskapismia, pakenemista siitä, mikä katsomuksen valossa on epäolennaista tai jää maailmamme ulkopuolelle. Tämä pakenemista ilmentävä piirre saattaa olla hyvin ilmeinen esim. sellaisissa filosofisissa tai uskonnollisissa opeissa, jotka olettavat, että ihmisen sielu on ruumiista erillinen olio ja että tämä ihmisen todellista olemusta edustava olio joko säilyy erillisenä ihmisen ruumiin hajotessa tai että sillä on jokin muu ruumiista erillinen kohtalonsa. Nämä käsitykset ovat pakenemista ilmentäviä, koska oletetaan, että sielu voi paeta aineellisesta elämästä ja että ihminen siis voi pitää arkista elämää vähäarvoisena ja väheksyä ihmisten välisiä arkisia suhteita. Eräissä opeissa pakenemista pyritään vaimentamaan asettamalla normeja, joita sielun tulisi ajallisen elämän aikana noudattaa, jotta se saavuttaisi sille mahdollisen parhaimman tavoitteensa. Usein nämä normit kuitenkin edustavat vain pakenemisen toisenlaista muotoa, edellyttävät ruumiin kurittamista, paastoamista, yksinäistä mietiskelyä ja maailmasta pakenemista tai keskittymistä vain uskovaisten seuraan.

Kristinusko alkukirkon aikana, jolloin elettiin Kristuksen uuden tulemisen odotuksessa, ei ollut samalla tavoin eskapistinen, vaikka se torjuikin voimakkaasti pakanallisen eli toisenlaisen maailman. Ei ole riittäviä perusteita kä- 
sitykselle, että ihminen Raamatun mukaan jakautuisi erikseen sieluun ja erikseen ruumiiseen. Mutta sikäli kuin kristinusko on tullut korostamaan yksipuolisesti oikean uskomisen ja siihen pohjautuvan sovituksen tärkeyttä, sen eskapististen piirteiden voi sanoa lisääntyneen. Keskiajalla tämä näkyi esim. siten, että hallitsijat, jotka olivat eläneet ja hallinneet kaikkea muuta kuin kristillisellä tavalla, sitten kuolinvuoteellaan katuivat julkisesti säätyjen edessä, määräsivät tekemänsä vääryydet korjattaviksi ja rahallisen hyvityksen maksettavaksi - saaden synninpäästön - mitä hyvityksiä seuraajat eivät kuitenkaan, hallitusta konkurssiin saattamatta, kyenneet sitten maksamaan, ja kaikki jatkui niinkuin ennenkin. Luther toi nämä ongelmat selvinä esiin. Hän myönsi julkisesti, että ihminen ei voi päästä sovintoon Jumalan taikka itsensä kanssa lakia noudattaen, hyviä tekoja tekemällä ja laskemalla eli ulkoisin suorituksin, tiedoin ja taidoin. Ristiriitojen ja pelkojen poistaminen vaatii, niinkuin edellä on eri tavoin koetettu osoittaa, syvempää omakohtaista muokkausta ja muutosta.

Jos filosofisten ja uskonnollisten oppien ulkopuolelta haluaa tieteen nykymaailmasta etsiä pakenemista osoittavia piirteitä, voisi viitata esim. avaruustutkimuksen ideologiaan. Jo ajatus, että ihmiskunta - kieltäydyttyään kohtuullisesta ja rauhallisesta vuorovaikutuksesta maapallon pinnalla ja saatettuaan sen vähemmän miellyttäväksi paikaksi — voisi siirtyä avaruuteen tai toisille planeetoille, on eskapismia sinänsä. Fyysikko Freeman Dyson kirjoitti joku vuosi sitten kirjan, jossa hän - jos olen häntä lainkaan ymmärtänyt - toi esiin uskonsa, että ihminen, mukautuen vähitellen elämään tyhjiös- sä ja siten myös taivaankappaleilla, joilla ei ole lainkaan ilmakehää, asuttaa koko Linnunradan ja kai muunkin avaruuden. Lukija jää ihmettelemään, mikä sellainen olento olisi ja olisiko hän ihminen, ja mitä intressiä ihmisellä olisi uurastaa tällaisen hypoteesin hyväksi. Kysymyksessä on kvasititeteellisen muodon saanut kuolemattomuusajatus, joka puhuu enemmän fysikaalisen tutkimuksen henkisestä tilasta kuin tieteen kyvystä ratkaista ihmisten ongelmia.

Filosofisiin, uskonnollisiin ja tieteellisiin käsityksiin sisältyvä todellisuudesta pakeneminen on sitä ilmeisempi, mitä suurempi on se fanaattisuus, jolla omaa oppia edustetaan ja vaaditaan ylimmäksi totuudeksi ja jolla jokaista muuta oppia tai elämisen tapaa vastustetaan ja yritetään tuhota. Äärimmäisyyksissään aatteet ja katsomukset, niinkuin oikeastaan kaikki muukin inhimillinen, ovat elämää tuhoavia, mutta keskialueillaan taas tärkeitä elämää säilyttäviä ja strukturoivia tekijöitä. Mitään läpikotaisin hyvää ideologiaa ei ole. Koulutuksen vaikeana tehtävänä on ohjata aatteellinen selvittely tälle keskialueelle, jossa keskustelu ja yhteistä elämää ylläpitävä keskinäinen inhimillinen vuorovaikutus on mahdollinen. Sen edellytyksenä on perusteita koskevien kysymysten salliminen ja tarkasteleminen. Sellainen erittely yleensä väistämättä johtaa sekä oman näkemyksen rajojen aavistamiseen että tavallisesti myös vastakkaisen näkemyksen kunnioittamiseen, toisin sanoen niiden edellytysten luominen, joiden vallitessa vuorovaikutus on mahdollinen. Sen aikaansaamista pitäisin aikuiskasvatuksen kaikkein tärkeimpänä tavoitteena. Keskinäinen vuorovaikutus ei ole aate eikä ajatus, se on ajaton haaste, perusosa yhteistä inhimillistä elämää. 